\title{
COMPARATIVE STUDY OF ITRAVENOUS NITROGLYCERINE AND CLONIDINE ON HAEMODYNAMIC STABILITY IN LAPROSCOPIC CHOLECYSTECTOMY.
}

P.K. Omar, S. K. Katiyar,Vineeta Gupta.

1. Assistant Professor Department of Anesthesiology, Rama Medical College Hospital \& Research Centre, Kanpur.

2. Associate Professor Department. of surgery, Rama Medical College Hospital \& Research Centre, Kanpur.

\section{CORRESPONDING AUTHOR:}

Dr. S. K. Katiyar M. S.,

FIAGES 675, Singhpur,

Kanpur- 208017.

E-mail: drskkatiyar59@rediffmail.com

ABSTRACT: Clonidine has been shown to reduce perioperative haemodynamic instability. The aim of the study was to investigate the clinical efficiency of intravenous clonidine premedication with nitroglycerine infusion in prevention of haemodynamic response associated with pneumoperitoneum.

Sixty adult patients of ASA physical status I\& II, scheduled for elective laparoscopic cholecystectomy were recruited for a prospective randomized, double-blinded comparative study. They were randomly allocated to one of the two groups to receive either nitroglycerine infusion (Group I) or i.v. clonidine $2 \mathrm{mg}$ (Group II), before induction of anaesthesia. Significant rise in heart rate was observed following pneumoperitoneum in Group I as compared to Group II (99.23 \pm 14.02 Vs $81.26 \pm 8.40 \mathrm{bpm})$. Similarly, while systolic arterial pressure, diastolic arterial pressure and mean arterial pressure changes were insignificant in both the groups following pneumoperitoneum. Nitroglycerine drip was started in 2 patients in Group II to control intraoperative hypertension. Incidence of postoperative nausea-vomiting and shivering was less in GroupII.

To conclude, clonidine premedication provides better perioperative haemodynamic stability, hence it can be recommended as a routine premedication for laparoscopic cholecystectomy.

INTRODUCTION: Laparoscopic cholecystectomy has revolutionized gall bladder surgeries and it has now become the "gold standard" of cholelithiasis [1]. It offers many benefits than conventional cholecystectomy, and has been promoted as a "gentle surgery". The number of cases continue to increase because of its clinical advantages in decreasing perioperative complications, postoperative pain and postoperative hospitalization compared to the conventional open technique.However, this procedure is not risk free.

In fact it produces significant haemodynamic changes specially in elderly and haemodynamically compromised patients. Pneumoperitoneum affects several homeostatic systems leading to alteration in acid-base balance, cardiovascular, pulmonary physiology and stress response. The extent of cardiovascular changes associated with pneumoperitoneum includes an 
increase in mean arterial pressure, decrease in cardiac output and increase in systemic vascular resistance which in turn compromise tissue perfusion.

Various pharmacological agents like nitroglycerine, $\beta$ blocker, and opioids are used to provide hemodynamic stability during pneumoperitoneum [4], but they have their own disadvantages. Nitroglycerine was used to correct the reduction of cardiac output associated with increased pulmonary occlusion pressure and systemic vascular resistance. Aho et al used á adrenergic receptor agonist for prevention of haemodynamic responses associated with laparoscopic surgery. They found that dexmedetomidine effectively reduces the maximum heart rate response after intubation and pneumoperitoneum. Clonidine inhibits the release of catecholamine and vasopressin and thus modulates the haemodynamic changes induced by pneumoperitoneum. [3]

Clonidine, a $\alpha-2$ adrenergic receptor agonist, has shown promising results for attenuation of hemodynamic response associated with laparoscopic surgery [4-8]. The present study was undertaken with the objective of evaluating the type and extent of hemodynamic changes during laparoscopic cholecystectomy and their modification by two different drugs i.e. intravenous nitroglycerine and intravenous clonidine.

Nitroglycerin is mainly used for the treatment and prevention of ischemic heart disease by dilating the coronary artery, systemic or focal veins with an ordinarily low dose which decreases preload and workload of the right ventricle and decreases the pulmonary artery pressure in addition to dilation of the pulmonary vessels. Nitroglycerin dose not induce remarkable changes in SVR at a low dose but induces a decrease in SVR by dilation of arterioles with a high dose. The usual dose of nitroglycerin is $0.5-2 \mu \mathrm{g} / \mathrm{kg} / \mathrm{min}$ while the dose used in this study was a relatively low at 0.5 $\mu \mathrm{g} / \mathrm{kg} / \mathrm{min}$, in consideration of the possibility that high dose nitroglycerin may induce severe hypotension in cases of hypovolemic states

OBJECTIVES OF STUDY: To study the influence of clonidine and nitroglycerine as intravenous infusion on the carbon dioxide pneumoperitoneum induced haemodynamic changes during laparoscopic surgeries

SOURCE OF DATA:- 60 patients undergoing elective laparoscopic surgeries under general anaesthesia in Rama medical college and Hospital Mandhana Kanpur, satisfying the inclusion criteria were randomized into two groups based on block randomization during the study period from October 2012 to March 2013.

\section{INCLUSION CRITERIA:-}

1. Patients belonging to ASA physical status 1 and 2.

2. Patients between 18-70 years.

3. Elective laparoscopic surgeries

\section{EXCLUSION CRITERIA:-}

1. Patients belonging to ASA physical status 3,4 and 5 .

2. Patients with Aortic Stenosis.

3. Patients with history of left ventricular failure. 
4. Patients with Atrioventricular Conduction Block.

5. Patients taking Clonidine, Beta blocking drugs, MAO inhibitors.

MATERIALS AND METHODS: After institutional review board approval and informed written consent from the patients, this prospective, randomized, double-blind controlled clinical study was carried out in 60 patients of either sex, aged 18-70 years, of ASA physical status I and II, scheduled for laparoscopic cholecystectomy under general anesthesia from Oct 2012 to March 2013. Exclusion criteria were patients with anticipated difficult airway; body mass index (BMI) $>25$, history of cardiopulmonary diseases; psychiatric illness; and therapy with $\alpha-2$ adrenergic agonists, $\beta$ blocker, methyldopa, MAO inhibitors, tricyclic antidepressant, and benzodiazepines.

In the pre-anesthetic preparation room, monitoring for heart rate (HR), non-invasive systolic blood pressure (SBP), diastolic blood pressure (DBP) and mean arterial pressure (MAP), peripheral oxygen saturation $\left(\mathrm{SpO}_{2}\right)$, and end-tidal $\mathrm{CO}_{2}\left(\mathrm{Et}^{\mathrm{CO}} \mathrm{C}_{2}\right)$ was instituted. Sedation was rated as per score shown in [Table 1].

Table 1

\begin{tabular}{|l|l|}
\hline SCORE & LEVEL OF SEDATION \\
\hline 0 & Awake and agitated \\
\hline 1 & Awake and comfortable \\
\hline 2 & Asleep and arousable \\
\hline 3 & Asleep with sluggish response to verbal commands or touch \\
\hline 4 & No response to verbal command or touch \\
\hline
\end{tabular}

Patients were randomly divided into two groups of 30 each. Group I received NITROGLYCERINE INFUSION@ $0.5 \mathrm{mcg} / \mathrm{kg} / \mathrm{min}$ from the time of intubation and group II, received, $2 \mu \mathrm{g} / \mathrm{kg}$ of clonidine in $100 \mathrm{ml}$ of normal saline before induction of anaesthesia. The drug was given over $15 \mathrm{~min}$ intravenously along with glycopyrrolate $0.004 \mathrm{mg} / \mathrm{kg}$ and tramadol $1.5 \mathrm{mg} / \mathrm{kg}, 30 \mathrm{~min}$ before induction of anesthesia.

Induction of anesthesia was done with intravenous propofol followed by succinyl choline, 2 $\mathrm{mg} / \mathrm{kg}$ to facilitate tracheal intubation; trachea was intubated with an appropriate sized cuffed, disposable endotracheal tube. Lungs were mechanically ventilated with $\mathrm{O}_{2}-\mathrm{N}_{2} \mathrm{O}$ (30-70), isoflurane (1-2\%), and vecuronium bromide $0.1 \mathrm{mg} / \mathrm{kg}$ bolus followed by $1 \mathrm{mg}$ intermittently for neuromuscular blockade. Tidal volume and ventilator frequency were adjusted to maintain normocapnia (EtCO ${ }_{2} 40 \pm 4 \mathrm{mmHg}$ ). Pneumoperitoneum (PP) was created by insufflations of $\mathrm{CO}_{2}$ and operation table was tilted to about 15 degree reversed trendelenberg. Intra-abdominal pressure was not allowed to exceed $15 \mathrm{mmHg}$. Throughout the study period, All the parameters selected ( $\mathrm{HR}, \mathrm{SBP}, \mathrm{DBP}, \mathrm{MAP}$, and $\mathrm{SpO}_{2}$ ) were recorded at specified timings. Any change in hemodynamic variables more than $20 \%$ on either side of baseline was considered significant. Any increase in MAP up to $20 \%$ from baseline was treated by increasing the concentration of isoflurane to a maximum 2\%. Any increase in MAP more than $20 \%$ from baseline was treated with nitroglycerine infusion. Nitroglycerine infusion was adjusted to maintain the MAP within $20 \%$ of baseline. Time duration from creation of pneumoperitoneum to the release of pneumoperitoneum was taken as duration of pneumoperitoneum. At the end of surgery, neuromuscular blockade was 
reversed with neostigmine $50 \mu \mathrm{g} / \mathrm{kg}$ and glycopyrrolate $10 \mu \mathrm{g} / \mathrm{kg}$ intravenously. After satisfying the extubation criteria, trachea was extubated and patients were transferred to post-anesthesia care unit (PACU). In PACU, HR, SBP, DBP, MAP, $\mathrm{SpO}_{2}$, sedation score, and any incidence of complications/adverse event were monitored for next $1 \mathrm{~h}$. Maintenance of MAP and $\mathrm{SpO}_{2}$ within $20 \%$ of baseline and sedation score $\leq 2$ was considered criteria for recovery. Sample size of minimum 29 per group was derived using Cohen's formula based on assumption of $\alpha$ error 0.05 and power of study $80 \%$ after permitting $\beta$ error of 0.2 to detect a difference of at least in the quantitative variables between the groups. Mean and standard deviation were calculated for all the quantitative variables using graph-pad prism statistical software. An intra-group comparison was made using paired Student's t-test and comparison between two groups at a time (inter-group comparison) was done using the unpaired t-test. $P<0.05$ was considered statistically significant.

OBSERVATION: All patients $(n=60)$ completed the study. Demographic parameters were comparable between groups $(P>0.05)$ [Table 2]. Duration of pneumoperitoneum in all the patients was 80 min or less except one patient in group I in whom the pneumoperitoneum lasted for $90 \mathrm{~min}$. As the monitored hemodynamic variables at 90 -min time point were not available in other groups, this time point was excluded. Two patients out of 30 in group 2 required nitroglycerine infusion for more than $20 \%$ rise in MAP above baseline.

In group III, a decrease in HR, SBP, DBP and MAP from baseline was observed within 15 min of clonidine premedication $(P<0.05)$, but at no time, this decrease was more than $20 \%$ from baseline. At tracheal intubation, HR and DBP increased $(P>0.05)$, while SBP decreased $(P>0.05)$ and MAP remained comparable to baseline. Within 40 min of pneumoperitoneum HR and within 20 min SBP, DBP, and MAP decreased $(P<0.05)$ and remained so throughout the study period Hemodynamic variables at the time of extubation remained comparable to baseline. All the patients maintained MAP comparable to baseline with $1 \%$ isoflurane. No patient in group III required nitroglycerine infusion. $\mathrm{SpO}_{2}$ remained stable and comparable to baseline in all the three groups.

Higher sedation score was observed in group II as compared to group I at specified timings $(P<0.05)$ but it never approached 2 at any time and no sign of respiratory depression observed. No patient in any group demanded supplemental analgesic up to $1 \mathrm{~h}$ postoperatively. $30 \%, 20 \%$, and $10 \%$ patients in group I had nausea, vomiting, and shivering respectively in the postoperative period while none had any complication in other two groups.

Table 2 Demographic Profile (Mean \pm SD)

\begin{tabular}{|l|l|l|l|l|}
\hline $\begin{array}{l}\text { Demographic } \\
\text { Profile }\end{array}$ & Group I & Group II & P Value & Significance \\
\hline Age (years) & $38.13 \pm 9.47$ & $36.13 \pm 9.17$ & 0.196 & NS \\
\hline Weight $(\mathrm{Kg})$ & $57.06 \pm 5.98$ & $56.16 \pm 5.28$ & 0.109 & NS \\
\hline Weight $(\mathrm{Kg})$ & $5: 25$ & $7: 23$ & 0.100 & NS \\
\hline ASA Grading & $\begin{array}{l}\text { Grade I }=26 \\
\text { Grade II }=4\end{array}$ & $\begin{array}{l}\text { Grade I }=26 \\
\text { Grade II }=4\end{array}$ & & \\
\hline
\end{tabular}




\section{ORIGINAL ARTICLE}

Table 3: Preoperative vital parameters (Mean \pm SD)

\begin{tabular}{|l|l|l|l|l|}
\hline Vital Parameters & Group II & Group II & P Value & Significance \\
\hline Pulse Rate $(\mathrm{bpm})$ & $79.1 \pm 7.81$ & $81.1 \pm 9.61$ & 0.357 & NS \\
\hline MAP (mm Hg) & $94.7 \pm 7.22$ & $92.5 \pm 8.62$ & 0.151 & NS \\
\hline Sp02 (\%) & $96.4 \pm 1.27$ & $96.4 \pm 1.17$ & 0.1 & NS \\
\hline Sedation Score & $1.23 \pm 0.43$ & $1.33 \pm 0.20$ & 0.065 & NS \\
\hline
\end{tabular}

Table 4: Changes in pulse rate in two groups

\begin{tabular}{|l|l|l|l|l|}
\hline $\begin{array}{l}\text { Diastolic Blood } \\
\text { Pressure (mm Hg) }\end{array}$ & $\begin{array}{l}\text { Group I (Mean } \\
\pm \text { SD) }\end{array}$ & $\begin{array}{l}\text { Group II } \\
\text { (Mean } \pm \text { SD) }\end{array}$ & P Value & Significance \\
\hline Before Premedication & $79.1 \pm 7.81$ & $79.1 \pm 7.81$ & 0.3540 & NS \\
\hline Before Induction & $89.1 \pm 7.81$ & $84.1 \pm 7.81$ & 0.085 & S \\
\hline After Intubation & $99.1 \pm 7.81$ & $89.1 \pm 7.81$ & 0.0069 & HS \\
\hline $\begin{array}{l}\text { Before } \\
\text { Pneumoperitoneum }\end{array}$ & $101.89 \pm 7.81$ & $92.1 \pm 7.81$ & 0.051 & HS \\
\hline $\begin{array}{l}\text { After } \\
\text { Pneumoperitoneum(15 } \\
\text { min) }\end{array}$ & $96.1 \pm 7.81$ & $85.1 \pm 7.81$ & 0.007 & HS \\
\hline $\begin{array}{l}\text { After } \\
\text { Pneumoperitoneum(30 } \\
\text { min) }\end{array}$ & $97.1 \pm 7.81$ & $83.1 \pm 7.81$ & 0.0043 & HS \\
\hline $\begin{array}{l}\text { After Release of Carbon } \\
\text { Dioxide }\end{array}$ & $81 \pm 7.81$ & $81.1 \pm 7.81$ & 0.01 & NS \\
\hline After Extubation & $110.1 \pm 7.81$ & $99.1 \pm 7.81$ & 0.0040 & HS \\
\hline
\end{tabular}

Table 5: Changes in systolic blood pressure in two groups

\begin{tabular}{|l|l|l|l|l|}
\hline $\begin{array}{l}\text { Diastolic Blood } \\
\text { Pressure (mm Hg) }\end{array}$ & $\begin{array}{l}\text { Group 1(Mean } \\
\pm \text { SD) }\end{array}$ & $\begin{array}{l}\text { Group 2(Mean } \\
\pm \text { SD) }\end{array}$ & $\begin{array}{l}\text { Group 3(Mean } \\
\pm \text { SD) }\end{array}$ & Significance \\
\hline Before Premedication & $119.1 \pm 7.81$ & $112.1 \pm 7.81$ & 0.345 & NS \\
\hline Before Induction & $121.1 \pm 7.81$ & $116.1 \pm 7.81$ & 0.300 & NS \\
\hline After Intubation & $126.1 \pm 7.81$ & $121.1 \pm 7.81$ & 0.091 & NS \\
\hline $\begin{array}{l}\text { Before } \\
\text { Pneumoperitoneum }\end{array}$ & $122.1 \pm 7.81$ & $115.1 \pm 7.81$ & 0.003 & HS \\
\hline $\begin{array}{l}\text { After } \\
\text { Pneumoperitoneum(15 } \\
\text { min) }\end{array}$ & $120.1 \pm 7.81$ & $117.1 \pm 7.81$ & 0.097 & NS \\
\hline $\begin{array}{l}\text { After } \\
\text { Pneumoperitoneum(30 } \\
\text { min) }\end{array}$ & $118.1 \pm 7.81$ & $115.1 \pm 7.81$ & 0.30 & NS \\
\hline $\begin{array}{l}\text { After Release of Carbon } \\
\text { Dioxide }\end{array}$ & $117.1 \pm 9.1$ & $113.1 \pm 7.81$ & 0.089 & NS \\
\hline After Extubation & $122 \pm 7.81$ & $120.1 \pm 7.81$ & 0.078 & NS \\
\hline
\end{tabular}




\section{ORIGINAL ARTICLE}

Table 6: Changes in mean arterial pressure in two groups

\begin{tabular}{|l|l|l|l|l|}
\hline $\begin{array}{l}\text { Diastolic Blood } \\
\text { Pressure (mm Hg) }\end{array}$ & $\begin{array}{l}\text { Group 1(Mean } \\
\pm \text { SD) }\end{array}$ & $\begin{array}{l}\text { Group 2(Mean } \\
\pm \text { SD) }\end{array}$ & $\begin{array}{l}\text { Group 3(Mean } \\
\pm \text { SD) }\end{array}$ & Significance \\
\hline Before Premedication & $89.1 \pm 7.81$ & $91.1 \pm 7.81$ & 0.342 & NS \\
\hline Before Induction & $1001 \pm 7.81$ & $94.1 \pm 7.81$ & 0.030 & HS \\
\hline After Intubation & $90.1 \pm 7.81$ & $91.1 \pm 7.81$ & 0.091 & NS \\
\hline $\begin{array}{l}\text { Before } \\
\text { Pneumoperitoneum }\end{array}$ & $92.1 \pm 7.81$ & $91.1 \pm 7.81$ & 0.099 & NS \\
\hline $\begin{array}{l}\text { After } \\
\text { Pneumoperitoneum(15 } \\
\text { min) }\end{array}$ & $91.1 \pm 7.81$ & $91.1 \pm 7.81$ & 0.097 & NS \\
\hline $\begin{array}{l}\text { After } \\
\text { Pneumoperitoneum(30 } \\
\text { min) }\end{array}$ & $90.1 \pm 7.81$ & $88 \pm 7.81$ & 0.30 & NS \\
\hline $\begin{array}{l}\text { After Release of Carbon } \\
\text { Dioxide }\end{array}$ & $85.1 \pm 9.1$ & $90.1 \pm 7.81$ & 0.089 & NS \\
\hline After Extubation & $122 \pm 7.81$ & $120.1 \pm 7.81$ & 0.078 & NS \\
\hline
\end{tabular}

Table 7: Changes in diastolic blood pressure in two groups

\begin{tabular}{|l|l|l|l|l|}
\hline $\begin{array}{l}\text { Diastolic Blood } \\
\text { Pressure (mm Hg) }\end{array}$ & $\begin{array}{l}\text { Group 1(Mean } \\
\pm \text { SD) }\end{array}$ & $\begin{array}{l}\text { Group 2(Mean } \\
\pm \text { SD) }\end{array}$ & $\begin{array}{l}\text { Group 3(Mean } \\
\pm \text { SD) }\end{array}$ & Significance \\
\hline Before Premedication & $81.1 \pm 7.81$ & $79.1 \pm 7.81$ & 0.342 & NS \\
\hline Before Induction & $841 \pm 7.81$ & $81.1 \pm 7.81$ & 0.030 & NS \\
\hline After Intubation & $84.1 \pm 7.81$ & $83.1 \pm 7.81$ & 0.091 & NS \\
\hline $\begin{array}{l}\text { Before } \\
\text { Pneumoperitoneum }\end{array}$ & $83.1 \pm 7.81$ & $80.1 \pm 7.81$ & 0.099 & NS \\
\hline $\begin{array}{l}\text { After } \\
\text { Pneumoperitoneum(15 } \\
\text { min) }\end{array}$ & $82.1 \pm 7.81$ & $81.1 \pm 7.81$ & 0.097 & NS \\
\hline $\begin{array}{l}\text { After } \\
\text { Pneumoperitoneum(30 } \\
\text { min) }\end{array}$ & $80.1 \pm 7.81$ & $78 \pm 7.81$ & 0.30 & NS \\
\hline $\begin{array}{l}\text { After Release of Carbon } \\
\text { Dioxide }\end{array}$ & $84.1 \pm 9.1$ & $80.1 \pm 7.81$ & 0.089 & NS \\
\hline After Extubation & $86 \pm 7.81$ & $80.1 \pm 7.81$ & 0.078 & NS \\
\hline
\end{tabular}

RESULTS: Three patients were withdrawn from the study because the proposed laparoscopic cholecystectomy surgery was converted to open cholecystectomy. Aside from these three patients, rest of the patients completed the analysis. Demographic profile and preoperative vital parameters were compared between the two groups of patients and no significant difference was found [Table 1]\& [Table 2]. Mean intra-abdominal pressure was $13.1 \pm 1.47 \mathrm{~mm} \mathrm{Hg}$ in Group I and Group II.. Normocapnia was maintained throughout the procedure. EtCO 2 varied from $31.13 \pm 3.45$ 
to35.46 $\pm 5.36 \mathrm{mmHg}$ in Group I, Group II. Mean pulse rate varied from $81.43 \pm 11.21$ to $113.17 \pm 13.33 \mathrm{bpm}$ in Group I and Group II. Upon statistical comparison in two groups of patients, no significant variation was observed throughout the intra operative period including the baseline value. [Table3].Changes in the blood pressure when compared was found to be statistically insignificant. [Table 4], [Table5], [Table6] and [Table7].

Patients remained haemodynamically stable in both the groups. Incidence of nauseavomiting, hypertension, shivering and shoulder pain were $35.70 \%, 35.70 \%, 10.7 \%$ and $14.3 \%$ in the Group I in Group II only 6.89\% patients suffered from nausea vomiting. Sedation was common in Group II (33.33\%). Other complications were not observed in Group II. None of the patient showed any evidence of ischaemia or arrhythmia intraoperatively.

DISCUSSION: Pneumoperitoneum during laparoscopy produces significant haemodynamic changes, which can be detrimental especially in elderly and haemodynamically compromised patients. [10]. Various techniques and pharmacological agents have been used to counteract these detrimental effects of pneumoperitoneum. This double blind prospective study was carried out in 60 adult patients, to compare the effect of nitroglycerine infusion and clonidine premedication in attenuating haemodynamic stress response associated with pneumoperitoneum. Clonidine, an imidazoline derivative is a selective áz adrenergic agonist. It is a potent antihypertensive drug. It produces a fall in the heart rate and blood pressure associated with decreased SVR and cardiac output. Dose of clonidine varied from 2 to $5 \mu \mathrm{g} . \mathrm{kg}^{-1}$ in different studies. Higher dose of clonidine (5 $\mu \mathrm{g} . \mathrm{kg}^{-1}$ ) is usually required for potentiation of postoperative analgesia by intrathecal morphine.[11]. A small oral dose of clonidine decreased the incidence of perioperative myocardial ischemic episodes without affecting haemodynamic stability. ${ }^{[8]}$ Aho et al [9] used $3 \mu \mathrm{g}^{2} \mathrm{~kg}^{-1}$ and $4.5 \mu \mathrm{g} . \mathrm{kg}^{-1}$ clonidine for suppression of haemodynamic response to pneumoperitoneum. Rise in blood pressure and heart rate was less in both the groups but 4.5

$\mu \mathrm{g} . \mathrm{kg}^{-1}$ clonidine produced greater fall in mean arterial pressure before induction. Joris et al ${ }^{[9]}$ used very high dose of clonidine $\left(8 \mu \mathrm{g} \cdot \mathrm{kg}^{-1}\right)$ for reducing the level of catecholamine and vasopressin following pneumoperitoneum. Malek et al ${ }^{[12]}$ used $150 \mu \mathrm{g}$ of clonidine as i.v. infusion and intramuscularly while Sung et al ${ }^{[13]}$ and Yu et al ${ }^{[14]}$ used $150 \mu \mathrm{g}$ of oral clonidine as premedication for maintenance of haemodynamic stability during pneumoperitoneum. Following pneumoperitoneum with carbon dioxide, patients were hyper ventilated to maintain normocapnia. Every effort was made to maintain intra abdominal pressure (IAP) below $14 \mathrm{~mm} \mathrm{Hg}$. Mean intraabdominal pressure was $13.1 \pm 1.47 \mathrm{~mm} \mathrm{Hg}$ in Group 1 and $12.7 \pm 1.15 \mathrm{~mm} \mathrm{Hg}$ in Group II. Haemodynamic changes associated with pneumo peritoneum were first recognized in 1947. [15] Diamant et al [16] reported 35\%decrease in cardiac output in dog with a raised intra abdominal pressure of $40 \mathrm{~mm} \mathrm{Hg}$. Ishizaki et al [17] tried to evaluate the safe intra-abdominal pressure during laparoscopic surgery. They observed significant fall in cardiac output at $16 \mathrm{~mm} \mathrm{Hg}$ of intra-abdominal pressure. Haemodynamic alterations were not observed at $12 \mathrm{~mm} \mathrm{Hg}$ of intraabdominal pressure. Based on all these observations the current recommendation is to monitor intra-abdominal pressure and to keep it as low as possible. Cunningham et al [20] and Dorsay et al ${ }^{[21]}$ assessed the ejection fraction (EF) of left ventricle by trans esophageal echocardiography during pneumoperitoneum. No significant change in ejection fraction was reported up to $15 \mathrm{~mm} \mathrm{Hg}$ 
of intra-abdominal pressure. Considering all these facts intra abdominal pressure was kept below $14 \mathrm{~mm} \mathrm{Hg}$.

In spite of maintaining normocapnia and keeping intra-abdominal pressure below $14 \mathrm{~mm}$ $\mathrm{Hg}$ significant rise in heart rate, systolic blood pressure, diastolic blood pressure and mean arterial pressure was noticed in Group P. Rise in systolic, diastolic and mean arterial pressure was more than $20 \%$ from the baseline. Slight fall in systolic blood pressure, diastolic blood pressure and mean arterial pressure was noticed following premedication with clonidine. Following intubation and pneumoperitoneum, increase in arterial pressure was noticed but it never crossed the base line value. Hence clonidine premedication was able to achieve haemodynamic stability during pneumoperitoneum.

Similar findings were reported by Aho et al [8], Joris et al [9], Malek et al [12], Sung et al [13], Yu et al $^{14]}$ and Laisalmi et al[20].

Aho et al ${ }^{[2]}$ observed that $4.5 \mu \mathrm{g} \cdot \mathrm{kg}^{-1}$ of clonidine significantly decreased the mean arterial pressure before induction of anaesthesia. So they recommended $3 \mu \mathrm{g} \cdot \mathrm{kg}^{-1}$ of clonidine for perioperative haemodynamic stability. Joris et al [9] used higher dose of clonidine for reduction of catecholamine and vasopressin associated with pneumoperitoneum. Clonidine significantly reduced the concentration of catecholamine but not vasopressin and cortisol concentration. Similarly Sung et al [13] observed haemodynamic stability during pneumoperitoneum with $150 \mu \mathrm{g}$ oral clonidine. Requirement of isoflurane was also less by $30 \%$ in the clonidine group. Yu et al [14]recommended the routine use of clonidine premedication in laparoscopic patients.

The adverse effects in the postoperative period were less in the patients who had clonidine premedication in comparison with nitroglycerine group. There was incidence of shivering in $10.70 \%$ patients in the group 1patients as compared to none in the clonidine group. This finding corroborates the finding of Nicolaou et al, where they concluded that clonidine inhibits cold thermoregulatory response due to an effect on central integration control and output from the thermoregulatory centers. [21]. Thus he opined that clonidine can be used as an effective agent for inhibition of perioperative shivering which can adversely increase metabolic rate and cardiac work and may also disrupt surgical repair or result in wound dehiscence.

Thirty five percent of patients of the Group I suffered from nausea and / or vomiting, while only $6.89 \%$ of the patients receiving clonidine had any such episode. Clonidine increases gastrointestinal motility by decreasing sympathetic outflow and increasing parasympathetic outflow from the central nervous system. Although many workers have reported the antiemetic property of clonidine, the mechanism by which it acts warrants further investigation.

CONCLUSION: Premedication with $2 \mu \mathrm{g} / \mathrm{kg}$ of IV clonidine, has been found to be relatively safe as well as effective method that provides stable hemodynamics and protection against stress response triggered by pneumoperitoneum in patients undergoing laparoscopic cholecystectomy. Clonidine also affords an added advantage of reduction in postoperative complications such as nausea-vomiting and shivering.

Although nitroglycerine infusion at a rate of $0.5 \mathrm{mcg} / \mathrm{kg} / \mathrm{min}$ from the time of intubation also attenuates the haemodynamic changes associated with carbon-dioxide associated pneumoperitoneum but fail to have other beneficial effects as compared to clonidine 
premedication.

Hence $2 \mu \mathrm{g} / \mathrm{kg}$ of IV clonidine can reasonably be recommended as premedicant for all laparoscopic procedures in otherwise healthy patients. However further study is required to find out its efficacy in patient with compromised cardiovascular system.

\section{REFERENCES:}

1. Cunningham AJ, Brull SJ. Laparoscopic Cholecystectomy: Anesthetic implications. Anaesth Analg 1993; 76:1120-33.

2. Aho $M$, Scheinin $M$, Lehtinen $A M$, et al. Intramuscularly administered dexmedetomidine attenuates haemodynamic and stress responses to gynecologic laparoscopy. Anesth Analg 1992; 75: 932-9.

3. Feig BW, Berger DH, Doughtery TB, Dupuis JF, His B, Hickey RC, et al. Pharmacologic intervention can reestablish baseline hemodynamic parameters during laparoscopy. Surgery 1994; 116:733-9.

4. Malek J, Knor J, Kurzova A, Lopourova M. Adverse hemodynamic changes during laparoscopic cholecystectomy and their possible suppression with clonidine premedication: Comparison with intravenous and intramuscular premedication. RozhlChir 1999;78:28691.

5. Sung CS, Lin SH, Chan KH, Chang WK, Chow LH, Lee TY. Effect of oral clonidine premedication on perioperative haemodynamic response and postoperative analgesic requirement for patients undergoing laparoscopic cholecystectomy. Acta Anaesthesiol Sin 2000; 38:23-9.

6. Laisalmi M, Koivusalo AM, Valta P, Tikkanen I, Lindgren L. Clonidine provides opioid sparing effect, stable haemodynamics and renal integrity during laparoscopic cholecystectomy. Surg Endosc 2001; 15:1331-5.

7. Raval DL, Mehta MK. Oral clonidine pre medication for attenuation of haemodynamic response to laryngoscopy and intubation. Indian J Anaesth 2002; 46:124-9.

8. Joris JL, Chiche JD, Canivet JL, Jacquet NJ, Legros JJ, Lamy ML. Hemodynamic changes induced by laparoscopy and their endocrine correlates: Effect of clonidine. J Am CollCardiol 1998; 32:1389-96.

9. Joris J, Chiche JD, Lamy M. Clonidine reduced haemodynamic changes induced by pneumoperitoneum during laparoscopic cholecystectomy. Br J Anaesth 1995; 74 (suppl): A124.

10. Dhoste K, Lacoste L, Karayan J, et al. Haemodynamic and ventilatory changes during laparoscopic cholecystectomy in elderly ASA III patients. Can J Anaesth 1996; 43:783-8.

11. Goyagi T, Nishikawa T. Oral Clonidine premedication causes the quality of postoperative analgesics by intrathecal morphine. Anesth Analg 1996; 82: 1192-6. ]

12. Malek KJ, Knor J, Kurzova A, Lopourova M. Adverse haemodynamic changes during laparoscopic cholecystectomy and their possible suppression with clonidine premedication. Comparison with intravenous and intramuscular premedication. Rozhl Chir 1999; 78: 28691. 
13. Sung CS, Lin SH, Chan KH, Chang WK, Chow LH, Lee TY. Effect of oral clonidine premedication on perioperative haemodynamic response and postoperative analgesic requirement for patients undergoing laparoscopic cholecystectomy. Acta Anaesthesiol Scand 2000; 38: 23-9.

14. Yu HP, Hseu SS, Yien HW, Teng YH, Chan KH: Oral clonidine premedication preserves heart rate variability for patients undergoing laparoscopic cholecystectomy. Acta Anaesthesiol Scand 2003; 47: 185-90.

15. Booker WM, French DM, Molano PA. Further studies on the acute effects of intra abdominal pressure. Am J Physiol 1947; 149: 292-8.

16. Diamant M, Benumot JL, Saidman LJ. Haemodynamics of increased intra-abdominal pressure: interaction with hypovolaemia and halothane anaesthesia. Anesthesiology 1978; 48: 23-7.

17. Ishizaki Y, Bandae Y, Shimomura K, Abe H, Ohtomo Y, Idezuki Y. Safe intra abdominal pressure of carbon dioxide pneumoperitoneum during laparoscopic surgery. Surgery 1993; 114: 549า-54.

18. Cunningham AJ, Turner J, Rosenbaum S, et al. Trans-oesophageal echocardiographic assessment of haemodynamic functions during laparoscopic cholecystectomy. Br J Anaesth 1993; 70: 621.

19. Dorsay GA, Greene FL, Baysinger CL. Haemodynamic changes during laparoscopic cholecystectomy monitored with trans oesophageal echocardiography. Surg Endosc 1995; 9: 128.

20. Laisalmi M, Koivusalo AM, Valta P, Tikkanen I, Lindgren L. Clonidine provides opioidsparing effect, stable haemodynamics and renal integrity during laparoscopic cholecystectomy. Surg Endosc 2001; 15: 1331-5.

21. Nicolaou G, Jonston CE, Bristow GK. Clonidine decrease vasoconstriction and shivering threshold, without affecting the sweating threshold. Can J Anaesth 1997; 44 (Suppl). : 63644. 